\title{
Cost-effectiveness of sentinel lymph node biopsy vs inguinofemoral lymphadenectomy in women with vulval cancer
}

\author{
A J Sutton ${ }^{*}, 1$, P Barton ${ }^{1}$, S Sundar ${ }^{2}$, C Meads ${ }^{3}$, A N Rosenthal ${ }^{4}$, P Baldwin ${ }^{5}, \mathrm{~K} \mathrm{Khan}^{3}$ and TE Roberts ${ }^{1}$ \\ ${ }^{1}$ Health Economics Unit, University of Birmingham, Birmingham, UK; ${ }^{2}$ Pan Birmingham gynaecological cancer centre, City Hospital \\ and School of Cancer Sciences, University of Birmingham, Birmingham, UK; ${ }^{3}$ Centre for Primary Care and Public Health, Barts and \\ The London School of Medicine and Dentistry, Queen Mary University of London, London, UK; ${ }^{4}$ Barts Cancer Institute, London, \\ UK and ${ }^{5}$ Addenbrooke's Hospital NHS Trust, Cambridge, UK
}

Background: This study examines the cost-effectiveness of sentinel lymph node biopsy, a potentially less morbid procedure, compared with inguinofemoral lymphadenectomy (IFL) among women with stage I and stage II vulval squamous cell carcinoma.

Methods: A model-based economic evaluation was undertaken based on clinical evidence from a systematic review of published sources. A decision tree model was developed with the structure being informed by clinical input, taking the perspective of the health-care provider.

Results: For overall survival for 2 years, IFL was found to be the most cost-effective option and dominated all other strategies, being the least costly and most effective. For morbidity-free related outcomes for 2 years, sentinel lymph node (SLN) biopsy with $99 \mathrm{mTc}$ and blue dye and haematoxylin \& eosin (H\&E) histopathology, with ultrastaging and immunohistochemistry reserved for those that test negative following H\&E is likely to be the most effective approach.

Conclusion: SLN biopsy using $99 \mathrm{mTc}$ and blue dye with ultrastaging may be considered the most cost-effective strategy based on the outcome of survival free of morbidity for 2 years. The findings here also indicate that using blue dye and H\&E for the identification of the SLN and the identification of metastasis, respectively, are not sensitive enough to be used on their own.

Vulval cancer represents $\sim 3-5 \%$ of all gynaecological malignancies and $1 \%$ of all female cancers (Hacker, 2005). It is more often seen in older women, although risk factors such as HPV (Macnab et al, 1986) and HIV (Elit et al, 2005) mean that it is also seen in younger women. In $90 \%$ of cases, it develops as a squamous cell carcinoma with the remainder being melanoma, Bartholin's gland tumours, adenocarcinoma and basal cell carcinomas.

Current treatment for early squamous cell vulval cancer consists of radical excision of the tumour with inguinofemoral lymphadenectomy (IFL) (van der Zee et al, 2008). This treatment is effective in terms of averting groin recurrence; however, it would ideally only be used in women with nodal metastasis. Given that only 25-35\% (de Hullu et al, 2000; Hampl et al, 2008) of women with presumed early-stage vulval cancer have metastasis this means that for $65-75 \%$ of women IFL will have been of no benefit, but patients will still be at increased risk from the significant morbidity resulting from the procedure (de Hullu et al, 2002). In the shortterm patients may suffer wound breakdown or infection, while in the long-term lower limb lymphedema and erysipelas (type of skin infection) can occur beyond 1 year (van der Zee et al, 2008). In spite of the morbidity of IFL, it has traditionally been preferred, as unrecognised disease in the inguinofemoral lymph nodes is associated with a very high risk of mortality.

An accurate test to identify metastasis in the inguinofemoral lymph nodes with a high degree of accuracy would mean that only women with confirmed nodal disease would receive IFL, thus 
sparing many women from the unnecessary morbidity associated with the procedure.

It has been shown that the various imaging modalities are not sufficiently sensitive strategies to identify women with groin metastases (Selman et al, 2005), and therefore pre-operative imaging of the groin is not a good strategy to identify women who should undergo IFL. Instead, sentinel lymph node (SLN) biopsy is used to identify and surgically excise the first draining lymph node from the primary cancer. The lymph node is then examined through histopathogical techniques to detect for the presence of metastasis. Only women that test positive for a metastasis would then go on to receive an IFL. Sentinel lymph node biopsy may consist of injection of one or both of blue dye and 99mTc (technetium-99m-labelled nanocolloid). A key advantage of these biopsy procedures is that they are associated with a much lower morbidity rate than IFL (van der Zee et al, 2008). However, it is acknowledged there is a risk that a false-negative SLN biopsy could result in a woman developing a groin recurrence with the associated higher risk of mortality (van der Zee et al, 2008).

In this study, we report the results of a model-based economic evaluation based on evidence from a systematic review of the literature that we carried out as part of a wider project to identify the most appropriate testing strategies for vulval cancer. The relative cost-effectiveness of undertaking a range of SLN biopsy options among women with presumed stage I or stage II vulval cancer compared with implementing ILF for all patients is examined.

\section{MATERIALS AND METHODS}

A systematic review assessing the effectiveness of SLN biopsy in the diagnosis and treatment of early-stage vulval cancer has already been conducted (Meads et al, 2013). This model-based economic evaluation relied exclusively on secondary data from the systematic review and takes the form of a cost-effectiveness analysis, carried out from a health-care provider perspective (in this case the UK NHS) in a secondary care (hospital) setting.

Model structure. A model was developed via consultation within the research team drawing on key clinical (SS, ANR and PB are all UK accredited gynaecological oncologists and regularly practice these procedures) and modelling expertise, using a decision tree in TreeAge Pro 2001 software (TreeAge Software Inc., Williamstown, MA, USA). It was felt that this approach would be most appropriate for the evaluation rather than use a Markov model due to the short-time horizon and there being no examples of the same event happening to the same patient (such as a single patient experiencing multiple groin recurrences over the 2-year time horizon) many times in the model structure. This choice of model structure is in line with published guidance, for example, Barton et al (2004); Brennan et al (2006).

Women enter the model having been identified, via prior histopathology of the primary lesion, as having presumed T1 (not T1a) or T2 FIGO stage unifocal vulval cancer. Only women with squamous cell carcinomas were considered; all other histological types were excluded due to their rarity and lack of adequate data for accurate modelling.

Seven different pathways are compared that describe alternative approaches to the SLN biopsy and the treatment of vulval cancer (referred to using square brackets in the text). The first pathway is the comparison arm (IFL without SLN biopsy), and is used to show how this more morbid treatment compares with different SLN biopsy options. In the case of pathways $2-7$, SLN biopsy is performed using either blue dye, $99 \mathrm{mTc}$, or both, in order to identify the SLN. This is followed by histopathology, which is a combination of haematoxylin and eosin (H\&E) staining and ultrastaging in order to test for the presence of metastasis, where ultrastaging can be considered to be representative of more sensitive techniques such as immunohistochemistry and additional sections. The impact of administering $\mathrm{H} \& \mathrm{E}$ as the routine histopathological examination alone is also examined. For women with metastasis detected by SLN biopsy an IFL is subsequently performed with radiotherapy also given where necessary (which may be necessary when more than one intranodal metastasis and/or extracapsular spread is detected (van der Zee et al, 2008)). Following an IFL, women are clinically monitored every 3 months for 2 years for evidence of recurrence. If women only receive SLN biopsy, then under these circumstances they are clinically monitored every 2 months for 2 years, which is the protocol for the UK. The seven patient treatment pathways are defined as shown in Table 1.

These treatment pathways are summarised in Figure 1 and the decision tree is shown in Figure 2. Further more detailed decision trees are given in the Appendices.

Clinical assumptions and parameterisation. The parameterisation of the model used in this economic evaluation was undertaken using the findings of a systematic review (Meads et al, 2013). In all cases where the results from multiple studies could be pooled to provide single-parameter values, these were always utilised. However, in cases where this was not possible, the results from

\begin{tabular}{|c|c|c|}
\hline No. & Treatment pathway & Description \\
\hline 1 & $\mathrm{IFL}$ & IFL for all patients, with no SLN biopsy. \\
\hline 2 & Blue dye $+\mathrm{H} \& \mathrm{E}$ & $\begin{array}{l}\text { Blue dye is injected around the tumour intraoperatively to identify the SLN. This is followed by histopathology } \\
\text { consisting of H\&E staining of the SLN in order to identify the presence of metastasis. }\end{array}$ \\
\hline 3 & Blue dye + ultrastaging & As for 2 but with ultrastaging of SLNs testing negative on routine H\&E. \\
\hline 4 & $99 m T c+H \& E$ & $\begin{array}{l}99 \mathrm{mTc} \text { (technetium-99m-labelled nanocolloid) is injected around the tumour preoperatively, and then pre-op } \\
\text { imaging is performed to confirm tracer-uptake in one or more SLNs. A probe is then used to detect the radioactive } \\
\text { signal at surgery to identify the SLN. This is followed by histopathology consisting of H\&E staining of the SLN to } \\
\text { identify the presence of metastasis. }\end{array}$ \\
\hline 5 & $99 \mathrm{mTc}+$ ultrastaging & As for 4 but with ultrastaging of SLNs testing negative on routine $\mathrm{H} \& \mathrm{E}$. \\
\hline 6 & Blue dye $+99 m T c+H \& E$ & $\begin{array}{l}\text { Both blue dye and } 99 \mathrm{mTc} \text { test are used to identify the SLN. Followed by H\&E staining to identify the presence of } \\
\text { metastasis. }\end{array}$ \\
\hline 7 & Blue dye $+99 \mathrm{mTc}+$ ultrastaging & As for 6 but with ultrastaging of SLNs testing negative on routine H\&E. \\
\hline
\end{tabular}




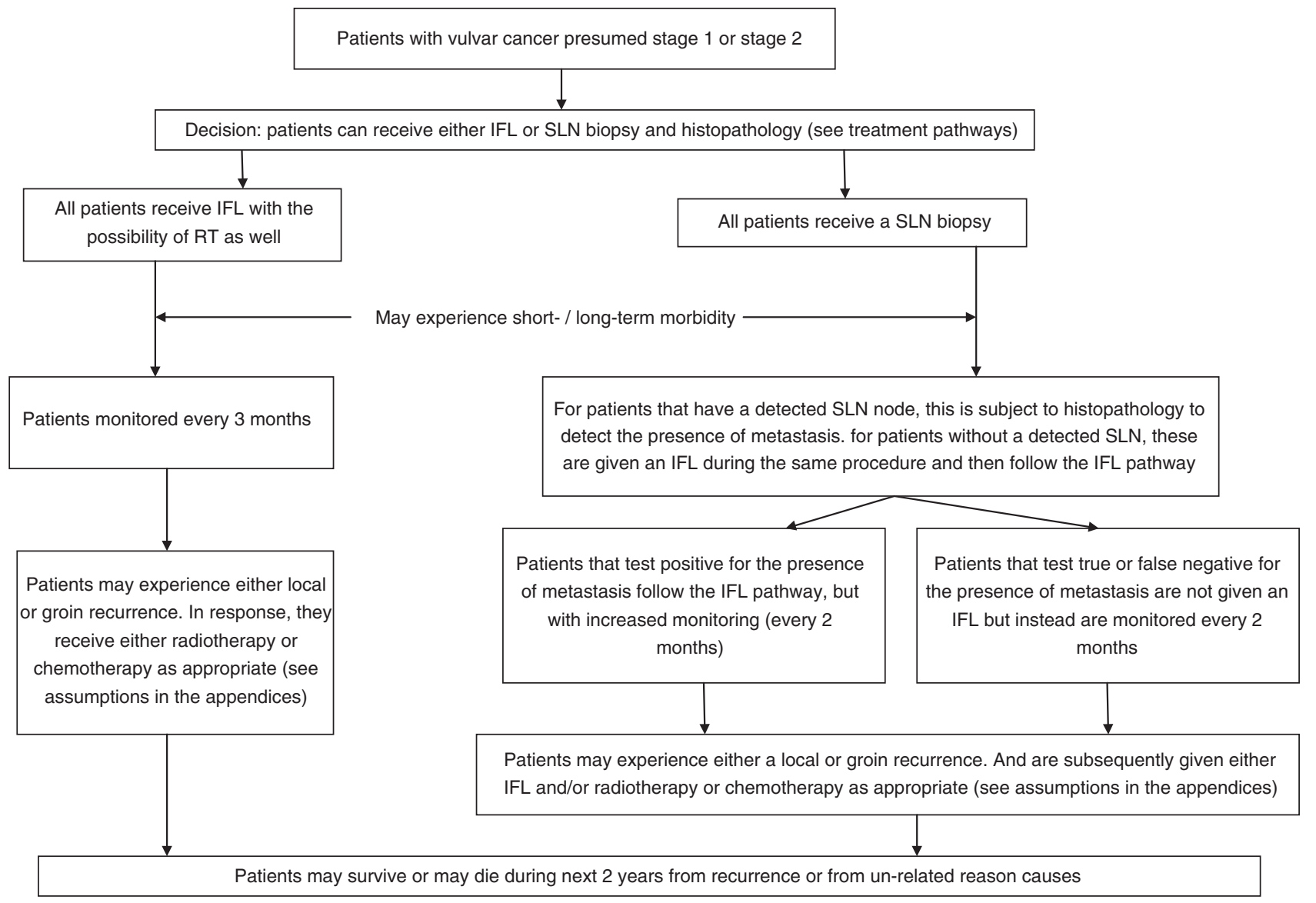

Figure 1. Summary of the decision pathway used in the economic model.

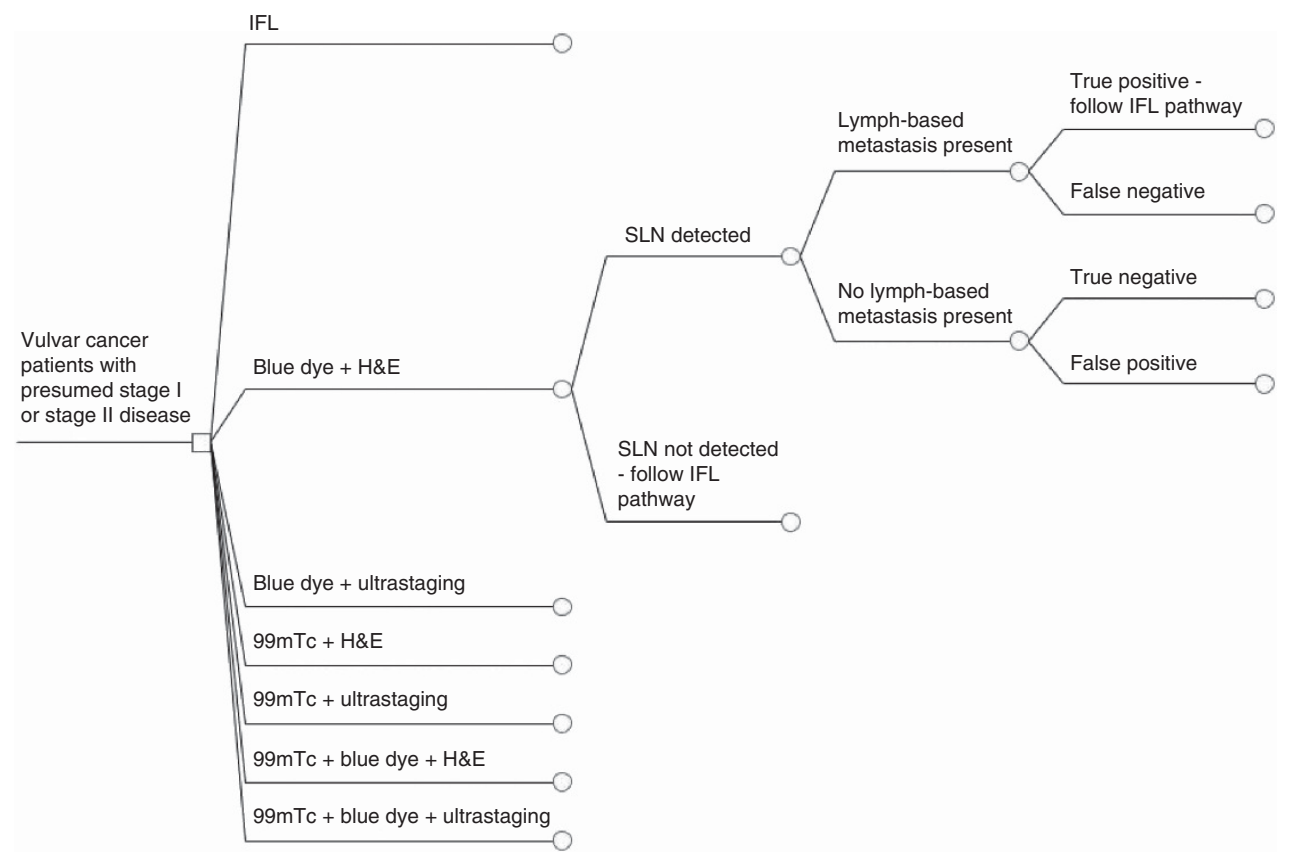

Figure 2. Model structure showing each of the seven primary treatment pathways, and the subsequent treatment pathway for blue dye $+\mathrm{H} \& \mathrm{E}$. This is repeated for each of the pathways that include either blue dye and/or $99 \mathrm{mTc}$.

larger more recent studies that were identified in the systematic review were preferred. The detection rates for the sentinel lymph node for the different types of SLN biopsy considered in this study are shown in Table 2. The application of the remaining parameters in the model are described in the appendices, while the assumptions that are required in order to develop a workable model structure and enable the analysis to be carried out are described in Table 3. These are broadly categorised as assumptions related to the general pathway, recurrence and further modelling. 
Table 2. Detection rates for SLN biopsies used in this analysis

\begin{tabular}{|l|l|l|}
\hline SLN biopsy & Value & Source \\
\hline Blue dye & $202 / 294(68.7 \%)$ & $\begin{array}{l}\text { Pooled values taken } \\
\text { from Systematic review } \\
\text { (Meads et al, 2013) }\end{array}$ \\
\hline $99 \mathrm{mTc}$ & $227 / 240(94.5 \%)$ & \\
\hline Blue dye $+99 \mathrm{mTc}$ & $1049 / 1074(97.7 \%)$ & \\
\hline
\end{tabular}

Abbreviation: $\mathrm{SLN}=$ sentinel lymph node.

\section{Table 3. Model assumptions}

\section{General Pathway-assumptions}

Patients found with a false-negative SLN biopsy (blue dye and/or 99mTc) who subsequently develop metastasis receive both IFL and radiotherapy.

Patients are followed-up every 2 months following a negative SLN biopsy result (and therefore do not receive $\mathrm{IFL}$ ) and every 3 months following an IFL.

There are no occasions in which radiotherapy might be administered to a patient who has not previously received an IFL (apart from following a recurrence).

Complications following a SLN biopsy (blue dye/99mTc) and then an IFL implemented during the same procedure will be the same as those experienced following an IFL.

Complications following all types of SLN biopsy (for example, blue dye/ $99 \mathrm{mTc}$ ) will be the same.

\section{Recurrence-assumptions}

Recurrence will only occur either in the groin or the vulva (local), distant recurrence will not be considered. This is because any distant recurrences, while rare are likely to occur following either a local or groin recurrence and rarely occur without either.

An additional primary excision will be required in the case of a local recurrence.

In the case of groin recurrence, the treatment is IFL + RT if it has not been administered already, chemotherapy will be administered if it has.

Mortality following recurrence within the 2-year time horizon is always due to vulval cancer, with these patients receiving palliative care as a result of their condition. Although it is acknowledged that the findings show that the death rate among vulval cancer patients due to vulval cancer or other causes is 50/ 50 following treatment, the risk of death following a recurrence is high enough for this assumption to be made.

\section{Further modelling-assumptions}

For the purpose of costing follow-up, all deaths from vulvar cancer and all other causes occur at 12 months following screening.

All parameters in this model are independent of age, with the exception of the all cause death rate. This assumption is made due to the paucity of age specific data in this field.

Patients experience long-term complications independently of whether they experience short-term complications. This assumption is made due to the paucity of data in the literature describing what proportion of patients experience both short-term and long-term complications.

Short-term and long-term morbidity have no impact on the mortality of the patients. This assumption is made due to paucity of data, however, its impact is investigated through sensitivity analysis.

All patients in the patient cohort are aged 65, the impact of this assumption is investigated through sensitivity analysis by examining patients aged 55 and 75 , respectively.

Abbreviations: $\mathrm{IFL}=$ inguinofemoral lymphadenectomy; $\mathrm{SLN}=$ sentinel lymph node
Cost and resource data. All costs in the model are in UK pounds sterling $£$ (2010 value). Three sources of data were used to parameterise the cost component of the economic evaluation. NHS Reference Costs 09/10, information provided by the Histopathology Department at Birmingham City Hospital and data collected as part of the United Kingdom Gynaecological Oncology Surgical Outcomes and Complications audit (UKGOSOC), which is a prospective web-based audit examining outcomes of surgery in gynaecological oncology particularly focused on complications. In all cases, patients only require a maximum of one unit of each cost depending on their treatment pathway, with the itemised costs shown in Table 4.

Costs are given for blue dye and $99 \mathrm{mTc}$ when administered separately, however, no cost was available for the two procedures combined, and therefore it is assumed that the cost for both blue dye and $99 \mathrm{mTc}$ is $10 \%$ greater than $99 \mathrm{mTc}$ alone (the more expensive of the two). The impact of this assumption on model results is examined through sensitivity analysis.

Outcomes. This economic evaluation focuses on how the different treatment scenarios impact on the mortality and morbidity of the patients and the costs of the different treatments. Therefore, the economic analysis is based on the following outcomes:

1. Case of death avoided for 2 years

2. Case of survival free of morbidity for 2 years

3. Case of survival free of long-term morbidity for 2 years.

The definitions of short-term and long-term morbidity in this study are the same as those proposed by van der Zee et al (2008) for complications, in which short-term morbidity is defined as the occurrence of wound breakdown or wound infection (requiring antibiotics); and long-term morbidity is defined as lymphedema present over two consecutive visits $>1$ year after primary therapy or recurrent erysipelas ( $>1$ episode of erysipelas requiring antibiotics).

For each of these outcomes, IFL is the reference scenario. There are no studies that have shown a difference in the QoL estimates for women that receive the different options considered in this analysis. Therefore, the option of using the QALY as an outcome measure was not available in this study.

The results are presented using the incremental cost-effectiveness ratio (ICER), which is defined as the difference in costs between two options divided by the difference in their effects (which in this case are the outcome measures described above) (Gray et al, 2011).

Analysis. The model estimates the mean costs associated with each of the treatment strategies and assumes that all women entering the model are aged 65 years, which is informed by the findings of the systematic review. The time horizon of the model is 2 years, which was chosen as any groin recurrences that might appear as a result of a false-negative SLN biopsy would be expected to be detected within this time frame (van der Zee et al, 2008). Owing to this short-time horizon with the majority of costs and events occurring in the first year, no discounting was applied.

Sensitivity analysis. Probabilistic and one-way sensitivity analyses were carried out in order to examine the robustness of the model results to uncertainties in the model parameters and the assumptions made. The one-way sensitivity analysis undertaken is described in Table 5:

\section{RESULTS}

Outcomes. For overall survival for 2 years, (IFL) was the most effective strategy. For all types of survival free of morbidity 
Table 4. Breakdown of costs used in the economic analysis

\begin{tabular}{|c|c|c|c|c|}
\hline Item & Code & Cost & Reference & Assumption \\
\hline $\begin{array}{l}\text { Radical excision } \\
\text { IFL (+ radical excision) } \\
\text { Radiotherapy } \\
\text { Chemotherapy } \\
\text { Monitoring of patients } \\
\text { One bed day }\end{array}$ & $\begin{array}{l}\text { MB01B } \\
\text { MA06Z } \\
\text { SC22Z + SC56Z } \\
\text { SB12Z+SB15Z } \\
503 \\
\text { MA06Z }\end{array}$ & $\begin{array}{l}£ 1971 \\
£ 4129 \\
£ 1728 \\
£ 1270 \\
£ 171 \\
£ 312\end{array}$ & $\begin{array}{l}\text { UKGOSOC data } \\
\text { UKGOSOC data } \\
\text { NHS reference costs } \\
\text { NHS reference costs } \\
\text { NHS reference costs } \\
\text { NHS reference costs }\end{array}$ & $\begin{array}{l}3.86 \text { (s.e. }=7.75 \text { ) bed days (range } 1-10 \text { ), administered on its } \\
\text { own in the case of a cancer recurrence: see assumptions in } \\
\text { appendix } \\
5.64 \text { (s.e. }=9.09 \text { ) bed days (range } 2-11 \text { ) } \\
\text { ' } 3 \text { Weeks of treatment, } 5 \text { days each week (assumption) } \\
\text { 'Inpatient' assume drugs from regime in band } 6 \\
\text { Procurement + Delivery } £ 779+£ 207+£ 284 \\
\text { Per/consultation. } \\
\text { Undertaken every } 2 \text { months for SLN pathways no. } 2-7 \text { (=12 } \\
\text { times over } 2 \text { years), every } 3 \text { months for IFL no. } 1 \text { pathway (=8 } \\
\text { times over } 2 \text { years) }\end{array}$ \\
\hline \multicolumn{5}{|c|}{ SLN biopsy (+ radical excision) } \\
\hline Blue dye +99mTc & $\begin{array}{l}\text { MA06Z } \\
\text { MA06Z + RA36Z } \\
\text { MA06Z + RA36Z }\end{array}$ & $\begin{array}{l}£ 3574 \\
£ 3836 \\
£ 4219\end{array}$ & $\begin{array}{l}\text { NHS reference costs } \\
\text { (UKGOSOC data for the } \\
\text { bed days) } \\
\text { NHS reference costs } \\
\text { (UKGOSOC data for the } \\
\text { bed days) } \\
\text { NHS reference costs } \\
\text { (UKGOSOC data for the } \\
\text { bed days) }\end{array}$ & $\begin{array}{l}3.86(\text { s.e. }=7.75) \text { bed days (range } 1-10) \\
3.86(\text { s.e. }=7.75) \text { bed days (range } 1-10) \\
3.86(\text { s.e. }=7.75) \text { bed days (range } 1-10)\end{array}$ \\
\hline \multicolumn{5}{|c|}{ Morbidity and mortality } \\
\hline $\begin{array}{l}\text { Short term } \\
\text { Long term } \\
\text { Vulval cancer-related } \\
\text { death }\end{array}$ & $\begin{array}{l}\text { MA06Z } \\
\text { MA06Z. } \\
502 \text { gynaecology } \\
\text { SD01A }\end{array}$ & $\begin{array}{l}£ 1635 \\
£ 702 \\
£ 436\end{array}$ & $\begin{array}{l}\text { NHS reference costs } \\
\text { NHS reference costs } \\
\text { NHS reference costs }\end{array}$ & $\begin{array}{l}\text { Mean }=5.24 \text { (s.e. }=5.24 \text { assumed) bed days (Selman, 2009) } \\
3 \text { Outpatient visits }+1 \text { bed day (assumed) } \\
\text { Specialist palliative care, inpatient }\end{array}$ \\
\hline \multicolumn{5}{|l|}{ Histopathology } \\
\hline $\begin{array}{l}\text { Haematoxylin and eosin } \\
\text { Ultrastaging }\end{array}$ & & $\begin{array}{l}£ 74.50 \\
£ 86.75\end{array}$ & $\begin{array}{l}\text { Histology department, } \\
\text { Birmingham City Hospital } \\
\text { Histology department, } \\
\text { Birmingham City Hospital }\end{array}$ & \\
\hline
\end{tabular}

\section{Table 5. Description of one-way sensitivity analysis}

\begin{tabular}{|c|c|c|c|}
\hline Parameter & Baseline value & Sensitivity analysis & Notes \\
\hline Age of the cohort & 65 & $40-80$ & Impacts on overall mortality rates \\
\hline $\begin{array}{l}\text { Increased mortality due to } \\
\text { patient morbidity }\end{array}$ & None & $\begin{array}{l}20 \% \text { Increase in overall } \\
\text { mortality rate for those that } \\
\text { experience morbidity }\end{array}$ & \\
\hline Cost of $99 m T c+$ blue dye & $£ 4219$ & $£ 3836-£ 5754$ & (See appendices for justification of sensitivity values) \\
\hline $\begin{array}{l}\text { Groin recurrence rate } \\
\text { following negative SLN } \\
\text { biopsy }\end{array}$ & $\begin{array}{l}\text { 6/259 (2.3\%) (van der Zee } \\
\text { et al, 2008) }\end{array}$ & $\begin{array}{l}2 / 31(6.5 \%) \text { (Moore et al, 2008) } \\
\text { and a more extreme } \\
\text { hypothetical value of } 30 \%\end{array}$ & $\begin{array}{l}\text { Van der Zee et al (2008) used at baseline, because it was a } \\
\text { much larger study. Moore study also lacked detail about uni-/ } \\
\text { bi-focal disease }\end{array}$ \\
\hline Frequency of monitoring & $\begin{array}{l}\text { Every } 3 \text { months for IFL, and } \\
\text { every } 2 \text { months for SLN } \\
\text { pathways ( } 2-7)\end{array}$ & $\begin{array}{l}\text { Every } 3 \text { months for all } \\
\text { pathways }\end{array}$ & \\
\hline $\begin{array}{l}\text { False-positive rate for SLN } \\
\text { biopsy pathways }\end{array}$ & $0 \%$ & $1.2 \%$ & $\begin{array}{l}1.2 \% \text { is } 95 \% \text { confidence interval value calculated from a } \\
\text { systematic review (Meads et al, 2013). Note there was no } \\
\text { evidence of any values below } 100 \% \text { being seen in the } \\
\text { literature }\end{array}$ \\
\hline
\end{tabular}


Table 6. Deterministic results for all strategies for the morbidity-related outcomes at 2 years

\begin{tabular}{|c|c|c|c|c|c|c|}
\hline Pathway & Cost & Incremental cost & Effectiveness & Incremental effectiveness & ICER & Remarks \\
\hline \multicolumn{7}{|l|}{ Survival for 2 years } \\
\hline $\begin{array}{l}\text { IFL } \\
\text { Blue dye + ultrastaging } \\
\text { Blue dye }+ \text { H\&E } \\
99 m T c+\text { ultrastaging } \\
99 m T c+\text { HE } \\
99 m T c+\text { blue dye }+ \text { ultrastaging } \\
99 m T c+\text { blue dye }+ \text { H\&E }\end{array}$ & $\begin{array}{r}£ 9367 \\
£ 9775 \\
£ 9826 \\
£ 10175 \\
£ 10245 \\
£ 10576 \\
£ 10648\end{array}$ & $\begin{array}{l}£ 408 \\
£ 400 \\
£ 400\end{array}$ & $\begin{array}{l}0.9645 \\
0.9427 \\
0.8782 \\
0.9345 \\
0.8457 \\
0.9335 \\
0.8418\end{array}$ & & & $\begin{array}{l}\text { Dominated } \\
\text { Dominated } \\
\text { Dominated } \\
\text { Dominated } \\
\text { Dominated } \\
\text { Dominated }\end{array}$ \\
\hline \multicolumn{7}{|c|}{ Survival free of morbidity for 2 years } \\
\hline $\begin{array}{l}\text { IFL } \\
\text { Blue dye + ultrastaging } \\
\text { Blue dye }+ \text { H\&E } \\
99 m T c+\text { ultrastaging } \\
99 m T c+\text { HE } \\
99 m T c+\text { blue dye }+ \text { ultrastaging } \\
99 m T c+\text { blue dye }+ \text { H\&E }\end{array}$ & $\begin{array}{r}£ 9367 \\
£ 9775 \\
£ 9826 \\
£ 10175 \\
£ 10245 \\
£ 10576 \\
£ 10648\end{array}$ & $\begin{array}{l}£ 408 \\
£ 400 \\
£ 400\end{array}$ & $\begin{array}{l}0.3512 \\
0.5241 \\
0.5015 \\
0.6054 \\
0.5744 \\
0.6151 \\
0.5830\end{array}$ & $\begin{array}{l}0.1729 \\
0.0813 \\
0.0097\end{array}$ & $\begin{array}{l}£ 2400 \\
£ 4900 \\
£ 41200\end{array}$ & $\begin{array}{l}\text { Dominated } \\
\text { Dominated } \\
\text { Dominated }\end{array}$ \\
\hline \multicolumn{7}{|c|}{ Survival free of long-term morbidity for 2 years } \\
\hline $\begin{array}{l}\text { IFL } \\
\text { Blue dye + ultrastaging } \\
\text { Blue dye }+ \text { H\&E } \\
99 \mathrm{mTc}+\text { ultrastaging } \\
99 \mathrm{mTc}+\mathrm{H \& E} \\
99 \mathrm{mTc}+\text { blue dye }+ \text { ultrastaging } \\
99 \mathrm{mTc}+\text { blue dye }+\mathrm{H \& E}\end{array}$ & $\begin{array}{r}£ 9367 \\
£ 9775 \\
£ 9826 \\
£ 10175 \\
£ 10245 \\
£ 10576 \\
£ 10648\end{array}$ & $\begin{array}{l}£ 408 \\
£ 400 \\
£ 400\end{array}$ & $\begin{array}{l}0.6423 \\
0.7534 \\
0.7105 \\
0.7985 \\
0.7395 \\
0.8039 \\
0.7430\end{array}$ & $\begin{array}{l}0.1111 \\
0.0451 \\
0.0054\end{array}$ & $\begin{array}{l}£ 3700 \\
£ 8900 \\
£ 74300\end{array}$ & $\begin{array}{l}\text { Dominated } \\
\text { Dominated } \\
\text { Dominated }\end{array}$ \\
\hline
\end{tabular}

the $(99 \mathrm{mTc}+$ blue dye + ultrastaging) strategy was found to be the most effective.

Costs. The (IFL) strategy was the cheapest, costing $£ 9367$ per women treated for presumed stage I or stage II vulval cancer. The most expensive was found to be the $(99 \mathrm{mTc}+$ blue dye $+\mathrm{H} \& \mathrm{E})$ strategy costing $£ 10648$ per patient (Table 6), which is due to the extra costs incurred as a result of the additional false-negative patients associated with this strategy having a groin node recurrence in the future, and receiving subsequent additional treatment and care.

Incremental analysis. In the case of the overall survival outcome for 2 years, the (IFL) strategy dominates all other strategies as it is both cheaper and averts the greatest mortality.

Results-survival free of morbidity for $\mathbf{2}$ years. For the outcome of survival free of morbidity for 2 years only the strategies of (blue dye + ultrastaging), (99mTc + ultrastaging) and $(99 \mathrm{mTc}+$ blue dye + ultrastaging) remain un-dominated by any of the alternative treatment strategies (Table 6).

In terms of survival free of morbidity for 2 years, the most effective strategy is the $(99 \mathrm{mTc}+$ blue dye + ultrastaging) strategy, but this comes at a greater cost, generating an ICER of $£ 41200$ compared with (99mTc + Ultrastaging) (costs $£ 400$ more than (99mTc + Ultrastaging) with an extra 0.0097 of effectiveness), meaning that the strategy requires an investment of $£ 41200$ to generate one additional case of survival free of morbidity compared with the strategy of $(99 \mathrm{mTc}+$ ultrastaging). The strategy of ( $99 \mathrm{mTc}+$ ultrastaging) is both slightly less effective in terms of overall survival free of morbidity and slightly less costly than $(99 \mathrm{mTc}+$ blue dye + ultrastaging). The ICER for $(99 \mathrm{mTc}+$ ultrastaging) is $\sim £ 4900$ compared with (blue dye + ultrastaging).
The ICER for (blue dye + ultrastaging) is $\sim £ 2400$ compared with (IFL), that is, a financial outlay of $£ 2400$ is necessary to generate one additional case of survival free of morbidity for 2 years compared with the (IFL).

Results-survival free of long-term morbidity for 2 years. With respect to survival free of long-term morbidity for 2 years, as with survival free of morbidity the strategies of (blue dye + ultrastaging), $(99 \mathrm{mTc}+$ ultrastaging) and (99mTc + blue dye + ultrastaging) remained un-dominated by any of the alternative treatment strategies (Table 6).

The most effective strategy is the $(99 \mathrm{mTc}+$ blue dye + ultrastaging) strategy, but this comes at a greater cost, generating an ICER of $£ 74300$, that is, the strategy requires an investment of $£ 74300$ to generate one additional case of survival free of longterm morbidity compared with the strategy of $(99 \mathrm{mTc}+$ ultrastaging). The strategy of $(99 \mathrm{mTc}+$ ultrastaging) is both slightly less effective in terms of overall survival free of long-term morbidity and slightly less costly than $(99 \mathrm{mTc}+$ blue dye + ultrastaging). The ICER for ( $99 \mathrm{mTc}+$ ultrastaging) is $\sim £ 8.900$, that is, an additional financial outlay of $£ 8900$ is necessary to generate one case of survival free of long-term morbidity compared with the strategy of (blue dye + ultrastaging).

Sensitivity analysis. The results of the sensitivity analysis are described in the Appendices. With respect to the one-way sensitivity analysis, only the cost of $99 \mathrm{mTc}$ and blue dye implemented during the same procedure has any impact on the conclusions drawn from the model. At baseline, it was assumed that this procedure would cost $10 \%$ more than the cost of $99 \mathrm{mTc}$ alone. However, if this was varied from being equal to the cost of $99 \mathrm{mTc}$ alone to costing $50 \%$ more than $99 \mathrm{mTc}$ alone, then this would lead the ICER values for $(99 \mathrm{mTc}+$ blue dye + ultrastaging $)$ 


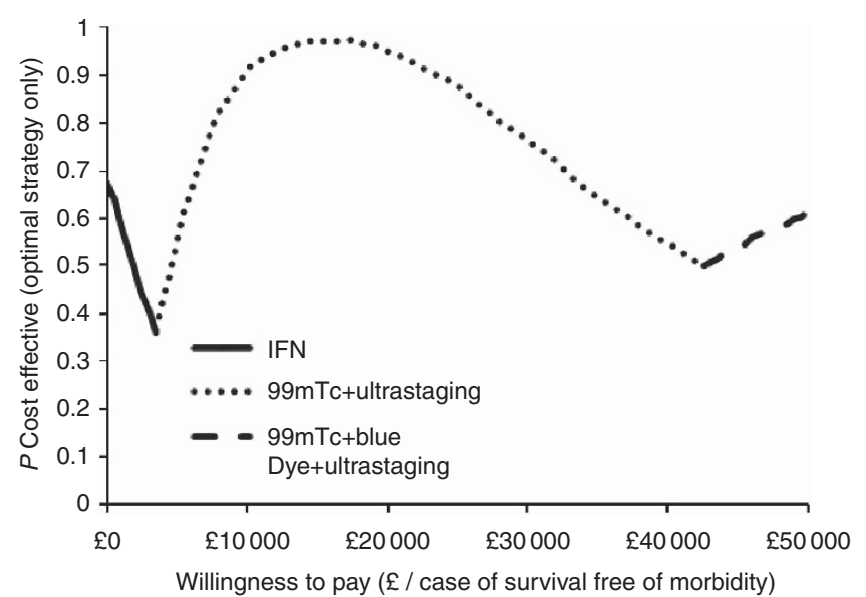

Figure 3. Cost-effectiveness acceptability frontier showing the results of the probabilistic sensitivity analysis examining the optimal treatment strategy across a range of willingness to pay thresholds for the outcome of additional case of survival free of morbidity for 2 years.

compared with (99mTc + ultrastaging) to range from $£ 4700$ $£ 195700$ and $£ 8400-£ 352600$ for a case of survival free of morbidity and survival free of long-term morbidity for 2 years, respectively.

Figure 3 shows the cost-effectiveness acceptability frontier from the probabilistic sensitivity analysis for the outcome of survival free of morbidity for 2 years. It can be seen that as the willingness to pay (WTP) crosses the ICER between two non-dominated strategies, the choice of optimal strategy changes, with a discontinuity in the curve being seen. Up to a WTP of $£ 3500$ the (IFL) strategy is the most cost-effective, and then from $£ 3500$ to $\sim £ 42000$ the $(99 \mathrm{mTc}+$ ultrastaging) strategy is the most costeffective, finally for a WTP greater than $\sim £ 42000$ the $(99 \mathrm{mTc}+$ blue dye + ultrastaging) strategy becomes the most cost-effective.

\section{DISCUSSION}

The results of the base-case analyses using the outcome of cost per death averted for 2 years have shown that for women with presumed stage I and stage II vulval cancer the treatment strategy of (IFL) is both less costly and more effective than any of the other strategies that utilise SLN biopsy. This result is not surprising given that this procedure seeks to reduce the potential for future recurrences at the expense of increased patient morbidity.

When considering the outcome measures of survival free of morbidity and survival free of long-term morbidity for 2 years the $(99 \mathrm{mTc}+$ ultrastaging) strategy, where ultrastaging is administered in the case of a negative $\mathrm{H} \& \mathrm{E}$ test was the most cost-effective strategy. It is also likely that the $(99 \mathrm{mTc}+$ ultrastaging + blue dye $)$ strategy is cost-effective when compared with that of $(99 \mathrm{mTc}+$ ultrastaging). However, there is some debate about this as it is difficult to judge the acceptability thresholds of the outcome measures used in this study (although some attempt is made below). This is in contrast to the QALY where there are clearer thresholds that can help to inform the acceptability of an intervention. It can therefore be concluded that the SLN biopsy that includes both $99 \mathrm{mTc}$ and ultrastaging is cost-effective in terms of the morbidity-free outcomes for 2 years compared with IFL, although there is some uncertainty about exactly what is the most cost-effective SLN biopsy option.

It is noted that the strategies that included blue dye only as the approach to the SLN biopsy, and H\&E only for the histopathology were never found to be cost-effective and were always dominated by other strategies (other strategies being less costly and more effective). This finding emphasises that using blue dye and $H \& E$ for the identification of the SLN and the identification of metastasis, respectively, are not sensitive enough to be used on their own.

Further one-way deterministic sensitivity analysis found that the cost of administering $99 \mathrm{mTc}$ and blue dye together has the potential to have a significant impact on the results obtained from this economic evaluation. As this is a combined technique in which two types of SLN biopsy are implemented in the same procedure, it is very difficult to obtain a well-informed cost for this approach. The results here demonstrate the importance of this parameter on the model results, but also reinforce the view that at the very least (99mTc + ultrastaging) is certainly a cost-effective approach to SLN biopsy.

This economic evaluation has had the advantage of being able to utilise the best available data in the model established in a systematic review of the evidence (Meads et al, 2013), particularly the sensitivity and specificity of the procedures used to identify the SLN and any metastasis. All assumptions used in the model were agreed by a panel of experts a priori, with key assumptions being examined through the use of sensitivity analysis. Owing to the scarcity of vulval cancer, many of the data points used in this model were based on quite small samples. However, the resultant uncertainly in these parameter values was examined through the use of probabilistic sensitivity analysis.

The major limitation of this study is the absence of preferencebased QoL estimates that differentiate between the impact of SLN biopsy and IFL on morbidity, making a cost-utility analysis using the QALY as the outcome measure impossible. This is unfortunate as there are thresholds for the acceptance of medical interventions using the QALY in the UK (Devlin and Parkin, 2004), which are not available for the outcome measures used in this study.

In order to provide some guidance as to the acceptability of the strategies considered in this research, an attempt is made to link the standard QALY thresholds to the morbidity-related outcomes used in this study. It can be said that a patient with 2 years survival free of morbidity will accumulate 2 QALYs within the time horizon of the model. Strictly this should be reduced to allow for discounting in the second year, but the difference will be small. A patient who either does not survive 2 years or who survives with appreciable morbidity may still accumulate some QALYs within the 2 years. Therefore, the value of an additional positive outcome using this measure is somewhat less than 2 QALYs. Using the upper NICE threshold of $£ 30000 /$ QALY (Devlin and Parkin, 2004), the WTP for an additional positive outcome would be somewhat less than $£ 60000$, although this is subject to the limitation that the 2 years time horizon means that no value is being attached to any survival beyond 2 years.

Instead of the QALY, three outcome measures have been considered in this study: overall mortality, survival free of morbidity and survival free of long-term morbidity, all considered over a maximum of 2 years. The inevitable difficulty with this selection is that it is very difficult to know which primary outcome measure is the most clinically relevant. Intuitively overall survival would seem to be best choice, however, in this setting this outcome provides little insight. IFL, while the cheapest strategy considered in this analysis, is a highly morbid procedure that is most effective at reducing the probability of a groin recurrence in the future and hence patient mortality. The option of SLN biopsy has been introduced into practice with the aim of reducing patient morbidity, but at the expense of the increased possibility of women having a false-negative diagnosis, with a resultant potential increase in mortality. Therefore, it was inevitable that in this study IFL has been shown to be the most effective procedure in terms of overall survival. Perhaps the most appropriate outcome measure in this study is survival free of morbidity, as this also incorporates all types of morbidity and the impact of overall survival into the 
outcome. Survival free of long-term morbidity has also been considered because oedema, which is a long-term complication, has been found to have a more significant impact on women treated with IFL compared with those receiving SLN biopsy (Oonk et al, 2009).

This analysis has highlighted the importance of obtaining overall QoL values that describe the impact of SLN biopsy and IFL and their related complications over time. A previous study attempted to identify these values but did not find a difference in overall QoL estimates between 62 women receiving either SLN biopsy or IFL despite the observed increased morbidity among women that underwent the IFL (Oonk et al, 2009). This may be because the study was too small to detect a difference or because of the type of QoL questionnaires administered, although this result could also be explained by the extra peace of mind that the IFL provides due to the increased possibility of a false-negative result with SLN biopsy. Intuitively there would need to be a difference in QoL between these two groups, as if this were not the case, IFL with its increased effectiveness at reducing the risk of a groin recurrence and therefore patient mortality, but with its much higher risk of morbidity, would always be preferred. Future work should be undertaken to examine QoL in these treatment groups using an alternative questionnaire and larger sample size.

\section{ACKNOWLEDGEMENTS}

This work was supported by the Health Technology Assessment, National Institute of Health Research, United Kingdom-project number 09/112/03.

\section{REFERENCES}

Barton P, Bryan S, Robinson S (2004) Modelling in the economic evaluation of health care: selecting the appropriate approach. J Health Serv Res Policy 9(2): 110-118.

Brennan A, Chick SE, Davies R (2006) A taxonomy of model structures for economic evaluation of health technologies. Health Econ 15(12): $1295-1310$.

Crosbie EJ, Winter-Roach B, Sengupta P, Sikand KA, Carrington B, Murby B, Slade RJ (2010) The accuracy of the sentinel node procedure after excision biopsy in squamous cell carcinoma of the vulva. Surg Oncol 19(4): e150-e154.

de Hullu JA, Hollema H, Lolkema S, Boezen M, Boonstra H, Burger MP, Aalders JG, Mourits MJ, van der Zee AG (2002) Vulvar carcinoma. The price of less radical surgery. Cancer 95(11): 2331-2338.

de Hullu JA, Hollema H, Piers DA, Verheijen RH, van Diest PJ, Mourits MJ, Aalders JG, van der Zee AG (2000) Sentinel lymph node procedure is highly accurate in squamous cell carcinoma of the vulva. J Clin Oncol 18(15): 2811-2816.

Devlin N, Parkin D (2004) Does NICE have a cost-effectiveness threshold and what other factors influence its decisions? A binary choice analysis. Health Econ 13(5): 437-452.
Elit L, Voruganti S, Simunovic M (2005) Invasive vulvar cancer in a woman with human immunodeficiency virus: case report and review of the literature. Gynecol Oncol 98(1): 151-154.

Fonseca-Moutinho JA (2005) Recurrent vulvar cancer. Clin Obstet Gynecol 48(4): 879-883.

Gray AM, Clarke PM, Wolstenholme JL, Wordsworth S (2011) Applied Methods of Cost-effectiveness Analysis. 1st edn. Oxford University Press: Oxford.

Hacker NF (2005) 'Vulvar cancer,' In Practical Gynaecologic Oncology, Berek JS, Hacker NF (eds) Williams \& Wilkins: Philadelphia, PA, USA, pp 585-602.

Hampl M, Hantschmann P, Michels W, Hillemanns P (2008) Validation of the accuracy of the sentinel lymph node procedure in patients with vulvar cancer: results of a multicenter study in Germany. Gynecol Oncol 111(2): $282-288$.

Macnab JC, Walkinshaw SA, Cordiner JW, Clements JB (1986) Human papillomavirus in clinically and histologically normal tissue of patients with genital cancer. N Engl J Med 315(17): 1052-1058.

Meads C, Sutton AJ, Makysiak S, Kowalska M, Zapalska A, Rogozinska E, Baldwin P, Rosenthal A, Ganesan R, Borowiack E, Barton P, Roberts T, Sundar S, Khan K (2013) Sentinel lymph node (SLN) status in vulval cancer: Systematic quantitative reviews and decision analytic model-based economic evaluation. HTA. Available at http://www.hta.ac.uk/2338 (Accessed 18 September 2013).

Moore RG, Robison K, Brown AK, Disilvestro P, Steinhoff M, Noto R, Brard L, Granai CO (2008) Isolated sentinel lymph node dissection with conservative management in patients with squamous cell carcinoma of the vulva: a prospective trial. Gynecol Oncol 109(1): 65-70.

Oonk MH, van Hemel BM, Hollema H, de Hullu JA, Ansink AC, Vergote I, Verheijen RH, Maggioni A, Gaarenstroom KN, Baldwin PJ, van Dorst EB, Van der Velden J, Hermans RH, van der Putten HW, Drouin P, Runnebaum IB, Sluiter WJ, van der Zee AG (2010a) Size of sentinel-node metastasis and chances of non-sentinel-node involvement and survival in early stage vulvar cancer: results from GROINSS-V, a multicentre observational study. Lancet Oncol 11(7): 646-652.

Oonk MH, van Hemel BM, Hollema H, de Hullu JA, Ansink AC, Vergote I, Verheijen RH, Maggioni A, Gaarenstroom KN, Baldwin PJ, van Dorst EB, Van der Velden J, Hermans RH, van der Putten HW, Drouin P, Runnebaum IB, Sluiter WJ, van der Zee AG (2010b) Size of sentinel-node metastasis and chances of non-sentinel-node involvement and survival in early stage vulvar cancer: results from GROINSS-V, a multicentre observational study. Lancet Oncol 11(7): 646-652.

Oonk MH, van Os MA, de Bock GH, de Hullu JA, Ansink AC, van der Zee AG (2009) A comparison of quality of life between vulvar cancer patients after sentinel lymph node procedure only and inguinofemoral lymphadenectomy. Gynecol Oncol 113(3): 301-305.

Selman TJ (2009) Non-invasive and minimally invasive diagnosis and therapy of lymphadenopathy in gynaecological cancers-Systematic reviews of the evidence. PhD University of Birmingham, Birmingham, UK.

Selman T.J., Luesley D.M., Acheson N., Khan K.S., Mann C.H. (2005) A systematic review of the accuracy of diagnostic tests for inguinal lymph node status in vulvar cancer. Gynecol Oncol 99(1): 206-214.

van der Zee AG, Oonk MH, de Hullu JA, Ansink AC, Vergote I, Verheijen RH, Maggioni A, Gaarenstroom KN, Baldwin PJ, van Dorst EB, Van der Velden J, Hermans RH, van der Putten H, Drouin P, Schneider A, Sluiter WJ (2008) Sentinel node dissection is safe in the treatment of early-stage vulvar cancer. J Clin Oncol 26(6): $884-889$. 


\section{APPENDIX A}

Detailed decision trees showing patient pathways.

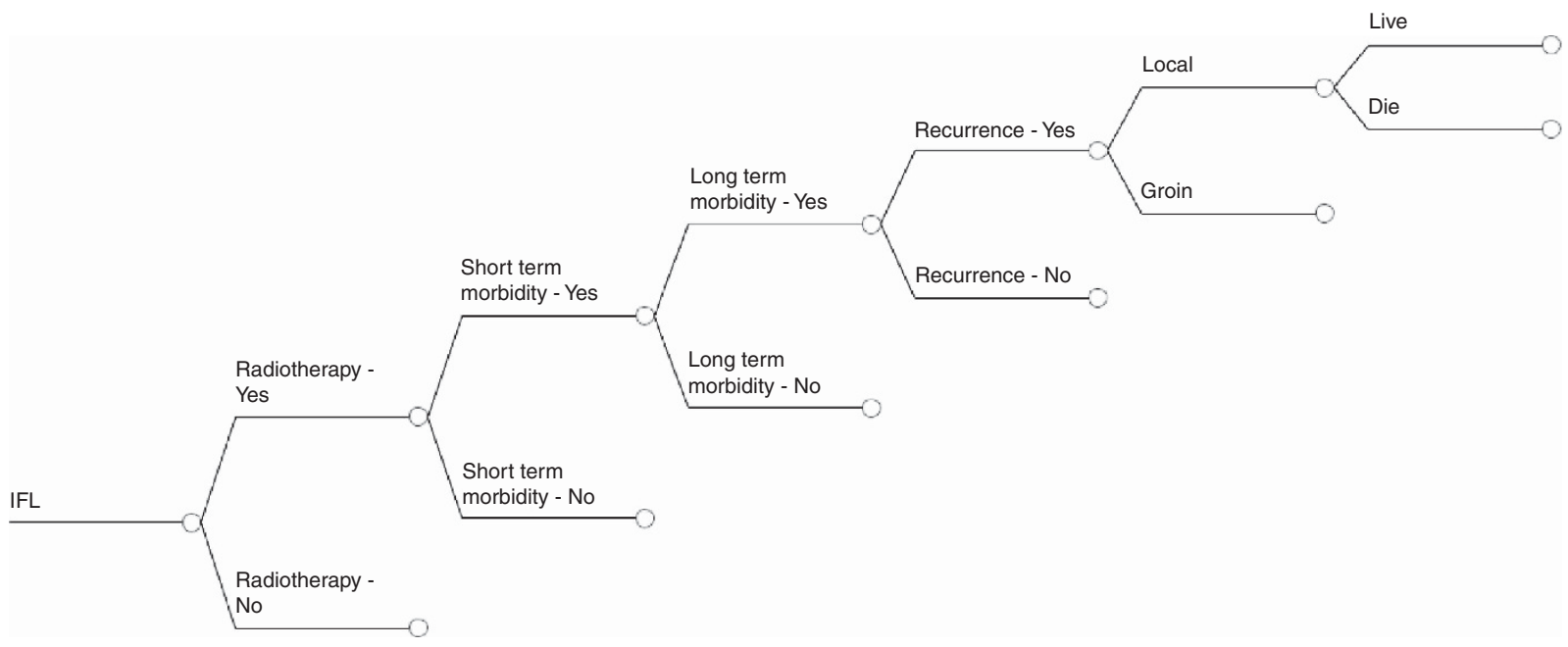

Figure A1: Treatment pathway following an IFL.

Note: Patients who have a local recurrence are given a primary excision. Patients who have a groin recurrence following IFL $+\mathrm{RT}$ are given chemotherapy. Patients who have a groin recurrence following an IFL only are given RT.

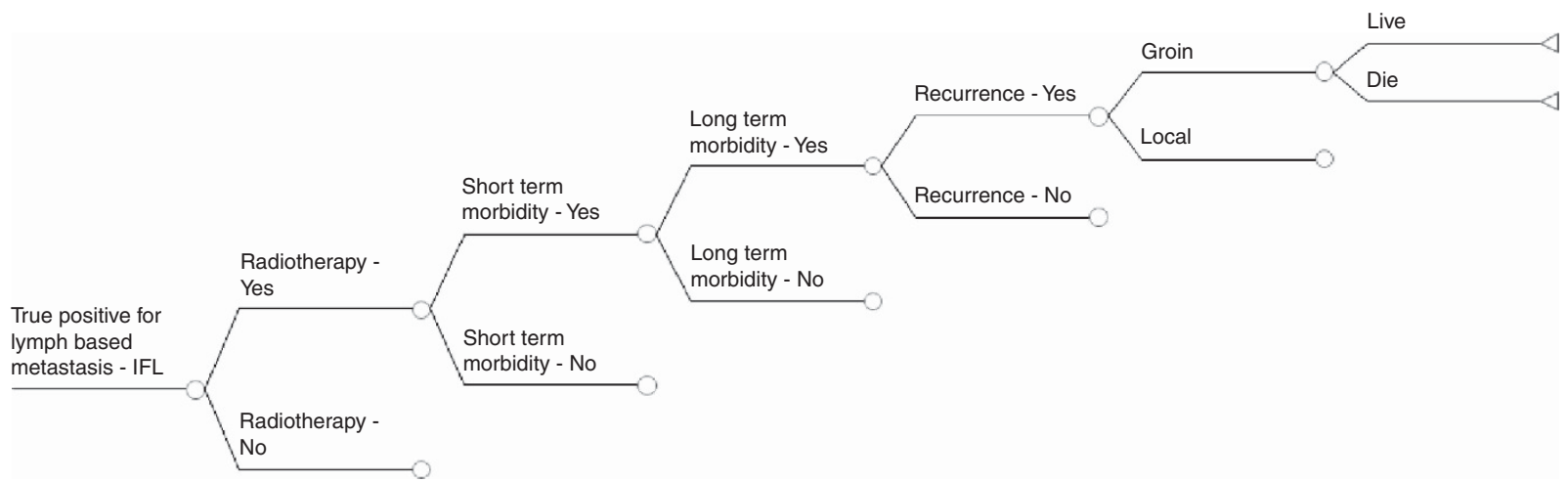

Figure A2: Treatment pathway for strategies 2-6 following a true-positive result for metastasis.

Note: Patients who have an IFL with or without RT may still go on to have either a local or groin recurrence. In the case of a local recurrence, all patients are given a primary excision. Patients who have a groin recurrence having previously received an IFL + RT are given chemotherapy, while for those who have only previously received an IFL are given RT.

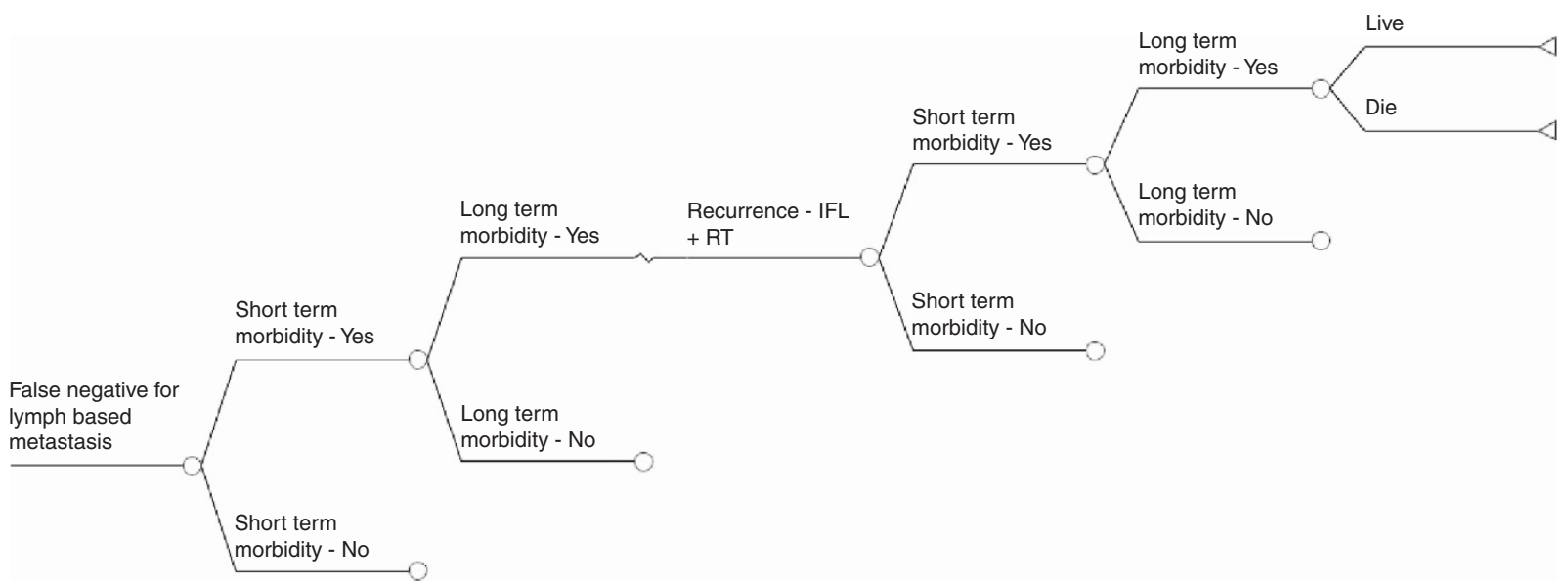

Figure A3: Treatment pathway for strategies 2-6 following a false-negative result for metastasis.

Note: Patients who have a false-negative biopsy test result, subsequently go on to have a groin recurrence. In this case, all the patients receive both an IFL + RT. 


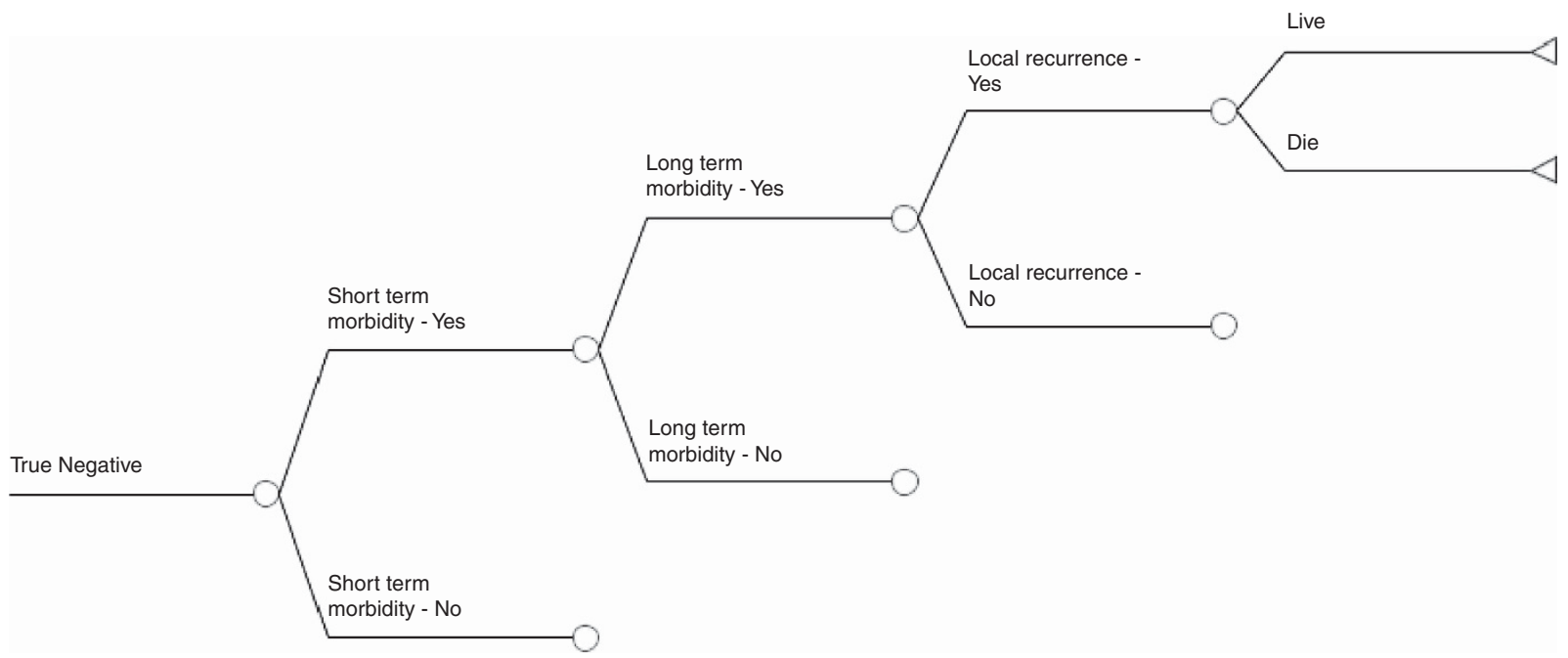

Figure A4: Treatment pathway for strategies 2-6 following a true-negative result for metastasis.

Note: Patients who have a true-negative biopsy test do not subsequently go on to have a groin recurrence. However, a local recurrence is still possible, and under these circumstances the patients are given a primary excision.

\section{APPENDIX B}

Table A1: Model parameters

\begin{tabular}{|l|c|c|c|}
\hline Parameter & Value & Reference & Notes \\
\hline Patients with metastasis & $33.5 \%$ & (van der Zee et al, 2008) & Examined in sensitivity analysis \\
Age of cohort & 65 & & \\
\hline
\end{tabular}

\section{Probabilities of recurrence}

\begin{tabular}{|c|c|c|c|}
\hline $\begin{array}{l}\text { Local recurrence } \\
\text { Groin recurrence following IFL (no SLN biopsy) } \\
\text { Groin recurrence followingnegative SLN biopsy result } \\
\text { Groin recurrence following positive SLN biopsy and IFL } \\
\text { Groin recurrence following false-negative test }\end{array}$ & $\begin{array}{c}34 / 276(12.3 \%) \\
1 / 32(3.1 \%) \\
\\
6 / 259(2.3 \%) \\
11 / 135(8.1 \%) \\
100 \%\end{array}$ & $\begin{array}{l}\text { (van der Zee et al, 2008) } \\
\quad \text { (Crosbie } \text { et al, 2010) } \\
\text { (van der Zee et al, 2008)) } \\
\text { (Oonk et al, 2010a, b) }\end{array}$ & $\begin{array}{c}\text { The possibility of local recurrence is present in all } \\
\text { arms of the model } \\
\text { Metastasis prevalence in this study found to be } 6 / 31 . \\
\text { Probability of groin recurrence given } \\
\text { metastasis }=0.1615 \\
\text { Patients with unifocal vulvar disease } \\
\text { By definition }\end{array}$ \\
\hline \multicolumn{4}{|c|}{ Death rates following recurrence and all cause } \\
\hline $\begin{array}{l}\text { Local Recurrence } \\
\text { Groin Recurrence } \\
\text { All cause }\end{array}$ & $\begin{array}{l}\text { 5/34 }(14.75 \%) \\
9 / 11(81.8 \%) \\
\text { Age } 40: 0.84 \% \\
\text { Age 65: } 1.97 \% \\
\text { Age } 80: 5.85 \%\end{array}$ & $\begin{array}{c}\text { (van der Zee et al, 2008)) } \\
\text { (Oonk et al, 2010a, b) } \\
\text { Office for National Statistics (2010) } \\
\text { (downloaded } 1 / 11 / 2011 \text { ) }\end{array}$ & $\begin{array}{l}\text { Calculated from: Natural Death rates. Mid-year } \\
\text { estimates published 30th June } 2011\end{array}$ \\
\hline \multicolumn{4}{|l|}{ Probabilities of requiring radiotherapy } \\
\hline $\begin{array}{l}\text { With an IFL strategy One } \\
\text { After a true-positive SLN biopsy result and IFL } \\
\text { After a false-positive biopsy result and IFL } \\
\text { Following a recurrence if not previously administered }\end{array}$ & $\begin{array}{c}(46.4 \%) 26 / 56 \\
(41.9 \%) 49 / 117 \\
0 \% \\
100 \%\end{array}$ & $\begin{array}{l}\text { (Fonseca-Moutinho 2005) } \\
\text { (van der Zee et al, 2008)) }\end{array}$ & $\begin{array}{l}\text { See assumptions } \\
\text { See assumptions }\end{array}$ \\
\hline \multicolumn{4}{|c|}{ Probabilities of morbidity in the short and long term } \\
\hline $\begin{array}{l}\text { Time frame } \\
\text { Short term }\end{array}$ & $\begin{array}{l}\text { Procedure } \\
\text { IFL (with/without SLN } \\
\text { biopsy) } \\
\text { SLN biopsy }\end{array}$ & $\begin{array}{c}\text { Complication } \\
\text { Wound breakdown } 34 \% \\
\text { Wound cellulitis } 21.3 \% \\
\text { Wound breakdown } 11.7 \% \\
\text { Wound cellulitis } 4.5 \%\end{array}$ & $\begin{array}{l}\text { \% Of patients with complications } \\
48.1 \%(22.6 / 47) \\
15.7 \%(41.4 / 264)\end{array}$ \\
\hline Long term & $\begin{array}{l}\text { IFL (with/without SLN } \\
\text { biopsy) and RT } \\
\text { IFL (with/without SLN } \\
\text { biopsy) no RT } \\
\text { SLN biopsy }\end{array}$ & $\begin{array}{c}\text { Lymphedema } 25.5 \% \\
\text { Recurrent erysipelas } 30.6 \% \\
\text { Lymphedema } 25.5 \% \\
\text { Recurrent erysipelas } 5.9 \% \\
\text { Lymphedema } 1.9 \%\end{array}$ & $\begin{array}{r}48.3 \%(23.7 / 49) \\
29.9 \%(20.9 / 70) \\
2.3 \%(6.1 / 264)\end{array}$ \\
\hline
\end{tabular}




\section{APPENDIX C}

Calculation of histopathology test accuracy parameters

The focus of this section is in linking data describing the prevalence of metastasis in the literature with the final outcomes for each of the histopathology testing strategies among patients that already have an identified SLN, namely, TP, FP, TN and FN.

Following the identification of the SLN(s) using a SLN biopsy, their histopathological assessment considered in this economic evaluation is the same as that described by van der Zee et al (2008). H\&E staining of the lymph node is used, and then if no metastasis is seen, ultrastaging with immunohistochemistry is then undertaken to confirm absence/presence of metastases.

The following calculations describe the possible outcomes for patients that have a detected SLN that is then subject to histopathology. As previously described, two approaches to histopathology are considered, these being $\mathrm{H} \& \mathrm{E}+$ ultrastaging and $\mathrm{H} \& \mathrm{E}$ alone. These are each considered in turn:

\section{H\&E + ultrastaging}

Among patients with an identified SLN that was subject to H\&E + ultrastaging, van der Zee et al (2008) describe that 6 out of 259 patients with unifocal vulval cancer and a negative SLN following H\&E and ultrastaging were subsequently diagnosed with a groin recurrence (giving a negative predictive value of 253/259 for H\&E and ultrastaging). And therefore by definition:

Number of false negatives $(\mathrm{FN})=6$

Number of true negatives $(\mathrm{TN})=253$

A systematic review (Meads et al, 2013) failed to find any evidence of patients testing false positive for metastasis (26 studies were considered), and so it is assumed here that $\mathrm{FP}=0$.

Taking the above values for $\mathrm{FN}$ and $\mathrm{TN}$, and the assumption that $\mathrm{FP}=0$, this means that the assumed prevalence of metastasis in this study cannot fall below $2.3 \%(6 / 259)$.

The number of disease (metastasis) negative (DN) can be calculated from the sum of the patients that test true negative (TN) and false positive (FP) for metastasis $(\mathrm{TN}+\mathrm{FP})$ :

$\mathrm{DN}=\mathrm{TN}+\mathrm{FP}$

As described in the table of parameters shown in Appendix B, the proportion of patients with metastasis (p) is taken to be 0.335 (135/403). From this, the number of disease (metastasis) positive (DP) can be calculated:

$\mathrm{DP}=\mathrm{DN} \times \mathrm{p} /(1-\mathrm{p})$

Taking the previously calculated values for FN and DP, the number of true positives can now be calculated:

Number of true positives $(\mathrm{TP})=\mathrm{DP}-\mathrm{FN}$

Now that we have values for FN, TN, FP and TP, which are based on values obtained from the literature, which include the assumed prevalence of metastasis, it is straightforward to calculate what proportion of patients will test for each of these possibilities for $\mathrm{H} \& \mathrm{E}+$ ultrastaging, with the baseline parameters shown in the Table below.

\section{For $\mathrm{H} \& \mathrm{E}$ alone}

As part of the study by Oonk, et al $(2010 \mathrm{a}, \mathrm{b}) 80$ out of 135 patients that were found to have metastasis were initially found positive by H\&E with the remainder being found positive through ultrastaging. This gives the sensitivity of $\mathrm{H} \& \mathrm{E}\left(\operatorname{Sens}_{\mathrm{H} \& \mathrm{E}}\right.$ ) to be $59 \%$
(80/135). However, this alone cannot be used to directly calculate the TP and FN values for H\&E, as the value for DP (used below) incorporates information on the negative predictive value of Ultrstaging + H\&E (253/259). This must also be considered here, as patients that have a groin recurrence after ultrastaging $+\mathrm{H} \& \mathrm{E}$ will certainly do the same for the less-sensitive option of $\mathrm{H} \& \mathrm{E}$ on its own.

Therefore, taking the number of disease (metastasis) positive (DP) described above for H\&E + ultrastaging, the number of true positives and false negatives detected by H\&E can be given as follows:

Number of true positives $\left(\mathrm{TP}_{\mathrm{H} \& \mathrm{E}}\right)=$ Sens $_{\mathrm{H} \& \mathrm{E}}{ }^{\star} \mathrm{DP}$

Number of false negatives $\left(\mathrm{FN}_{\mathrm{H} \& \mathrm{E}}\right)=\mathrm{DP}-\mathrm{TP}_{\mathrm{H} \& \mathrm{E}}$

Taking the number of true negatives detected by $\mathrm{H} \& \mathrm{E}\left(\mathrm{TN}_{\mathrm{H} \& \mathrm{E}}\right)$ to be the same as for $\mathrm{H} \& \mathrm{E}+$ ultrastaging and again assuming that $\mathrm{FP}_{\mathrm{H} \& \mathrm{E}}=0$.

The values for $\mathrm{FN}_{\mathrm{H} \& \mathrm{E}}, \mathrm{TN}_{\mathrm{H} \& \mathrm{E}}, \mathrm{FP}_{\mathrm{H} \& \mathrm{E}}$, and $\mathrm{TP}_{\mathrm{H} \& \mathrm{E}}$ allow the proportion of patients that test for each of these possibilities for $\mathrm{H} \& \mathrm{E}$ alone to be calculated, with the values used at baseline shown in Table 4.

In all cases, the values taken from the literature, for example, prevalence of metastasis, are varied as part of the probabilistic sensitivity analysis in order to show their impact on the model results.

Table A2: Parameters describing outcomes of H\&E and ultrastaging amongst patients with an identified sentinel lymph node

\begin{tabular}{|l|c|c|}
\hline Test result & H\&E & $\begin{array}{c}\text { H\&E if negative } \\
\text { then ultrastaging }\end{array}$ \\
\hline False negative & $13.6 \%$ & $1.6 \%$ \\
\hline True negative & $66.5 \%$ & $66.5 \%$ \\
\hline False positive & $0.0 \%$ & $0.0 \%$ \\
\hline True positive & $19.9 \%$ & $31.9 \%$ \\
\hline
\end{tabular}

\section{APPENDIX D}

\section{Probabilistic sensitivity analysis}

The results described by the cost-effectiveness point estimates do not consider any uncertainty in relation to the model input parameters. Probabilistic sensitivity analysis (PSA) was therefore undertaken to assess the impact of the uncertainty in the model parameters on the results and conclusions obtained from the model. The costs in the model are all unit costs for specific procedures and are treated as fixed, however the number of bed days were varied. The probabilities in the tree, these being the proportions of patients that follow each branch were also varied.

The standard distribution used in this analysis for the proportions is the beta distribution. The beta distribution is described by two parameters a and $\mathrm{b}$. A beta $(\alpha, \beta)$ distribution is able to precisely represent the uncertainty in a proportion when the only available information is $\alpha$ positive cases and $\beta$, negative cases. In all cases in this study exact numbers were available, and so these were used to inform the parameters of each Beta distribution directly. The bed days were described by a gamma distribution. The method of moments approach was used to estimate the parameters of the gamma distribution, where:

$$
\begin{aligned}
& \alpha=\left(\text { mean }^{\wedge} 2\right) /\left(\text { s.e. }^{\wedge} 2\right) \\
& \beta=\left(\text { s.e. }{ }^{\wedge} 2\right) /(\text { mean })
\end{aligned}
$$


Table A3: Distributions used in the probabilistic sensitivity analysis

\begin{tabular}{|c|c|c|c|}
\hline Parameter & Distribution & alpha & beta \\
\hline Patients with metastasis* & Beta & 135 & 268 \\
\hline Blue dye detection rate & Beta & 202 & 92 \\
\hline 99mTc detection rate & Beta & 227 & 13 \\
\hline Blue dye $+99 \mathrm{mTc}$ detection rate & Beta & 1050 & 25 \\
\hline Negative predictive value of $\mathrm{H} \& \mathrm{E}+$ ultrastaging $^{*}$ & Beta & 253 & 6 \\
\hline Sensitivity of H\&E & Beta & 80 & 55 \\
\hline Local recurrence & Beta & 34 & 242 \\
\hline Groin recurrence following IFL (no SLN biopsy) & Beta & 1 & 31 \\
\hline Groin Recurrence following positive SLN biopsy and IFL & Beta & 11 & 124 \\
\hline Death following a local recurrence & Beta & 5 & 29 \\
\hline Death following a groin recurrence & Beta & 9 & 2 \\
\hline RT following IFL in the comparison arm & Beta & 26 & 30 \\
\hline RT with IFL following a true positive histopathology result & Beta & 49 & 68 \\
\hline Short-term morbidity following IFL & Beta & 22.6 & 24.4 \\
\hline Short-term morbidity following SLN biopsy & Beta & 41.4 & 222.6 \\
\hline Long-term morbidity following IFL + RT & Beta & 23.7 & 25.3 \\
\hline Long-term morbidity following IFL without RT & Beta & 20.9 & 49.1 \\
\hline Long-term morbidity following SLN Biopsy & Beta & 6.1 & 257.9 \\
\hline Bed days following a primary excision/SLN biopsy & Gamma & 1.925 & 2.007 \\
\hline Bed days following a IFL & Gamma & 3.504 & 1.610 \\
\hline
\end{tabular}

Abbreviations: $\mathrm{H \& E}=$ haematoxylin and eosin; $\mathrm{IFL}=$ inguinofemoral lymphadenectomy; $\mathrm{SLN}=$ sentinel lymph node.

${ }^{\star}$ It is assumed that the negative predictive value of $\mathrm{HE}+$ ultrastaging is independent of the proportion of patients with metastasis.

\section{APPENDIX E}

\section{Sensitivity analysis—results}

Probabilistic sensitivity analysis

Survival at 2 years

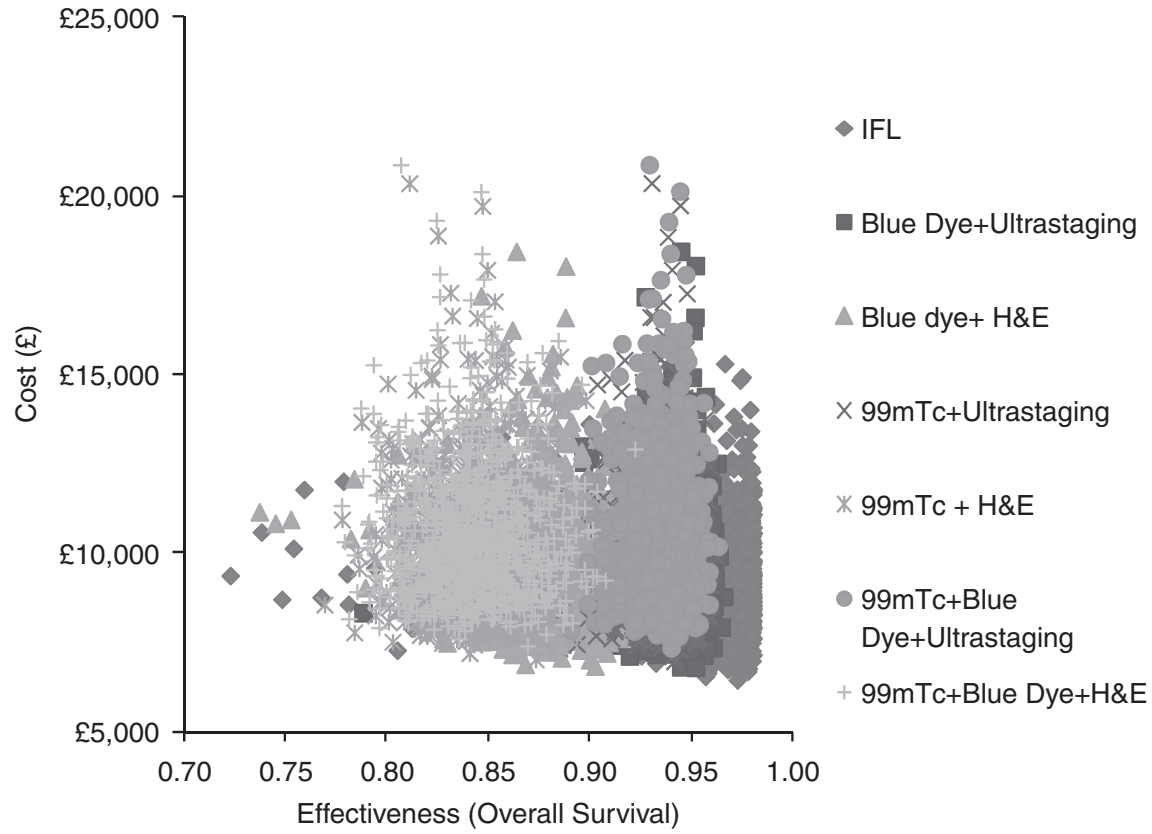

Figure A5: Scatterplot showing the uncertainty in costs and effectiveness within the model for each of the seven strategies for 1000 runs with overall survival for 2 years as the outcome measure

For all values of a WTP from $£ 0$ to $£ 100000$ for the overall survival outcome measure, the (IFL) strategy was found to be the most cost-effective, and so the cost-effectiveness acceptability frontier for overall survival for 2 years is not shown. 
Survival free of morbidity for 2 years

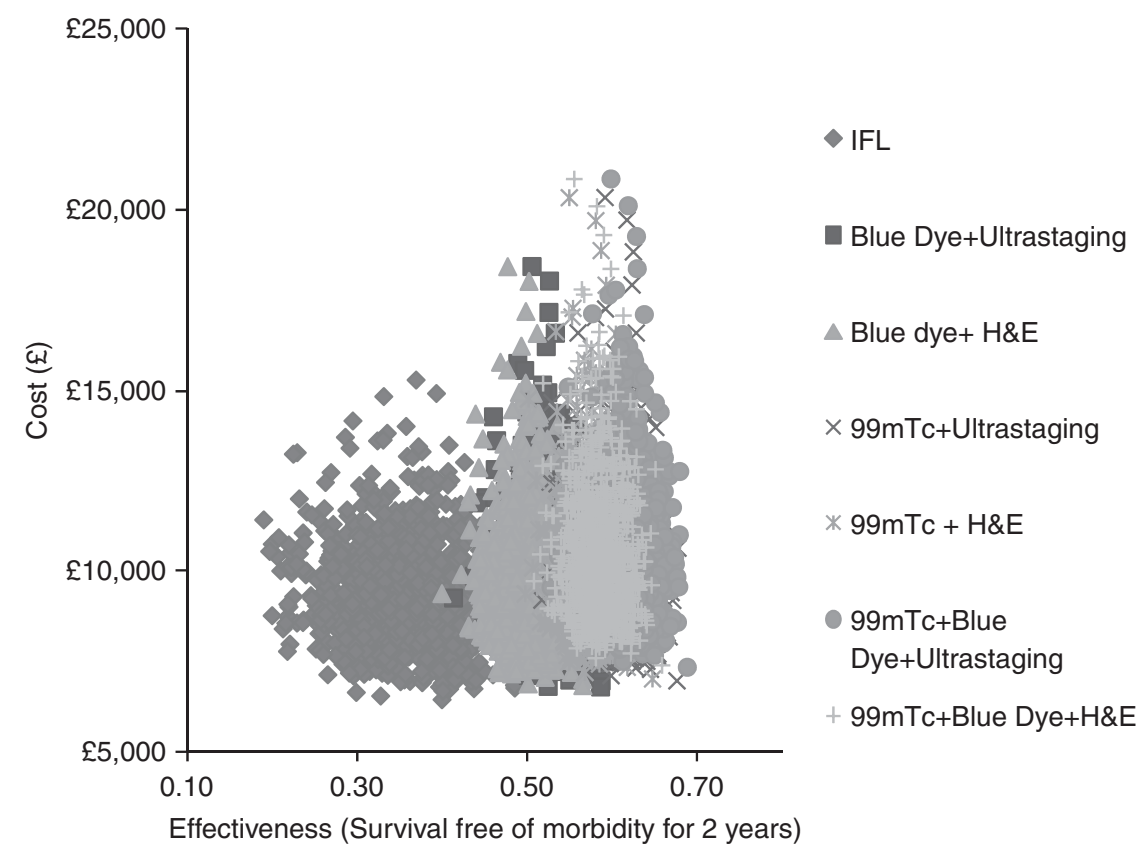

Figure A6: Scatterplot showing the uncertainty in costs and effectiveness for each of the seven strategies for 1000 runs with survival free of morbidity as the outcome measure

See manuscript for cost-effectiveness acceptability frontier for the outcome measure of survival free of morbidity for 2 years.

Survival free of long-term morbidity for 2 Years

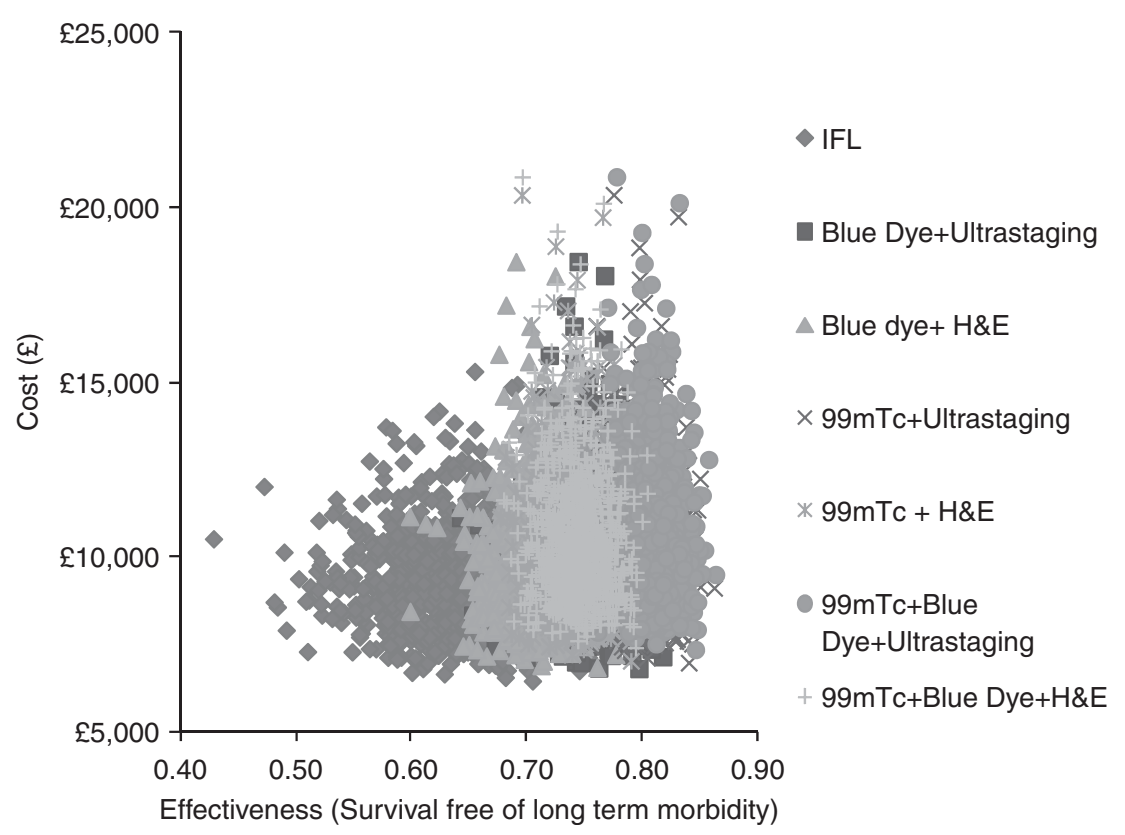

Figure A7: Scatterplot showing the uncertainty in costs and effectiveness within the model for each of the 7 strategies for 1000 runs with survival free of long-term morbidity for 2 years as the outcome measure 


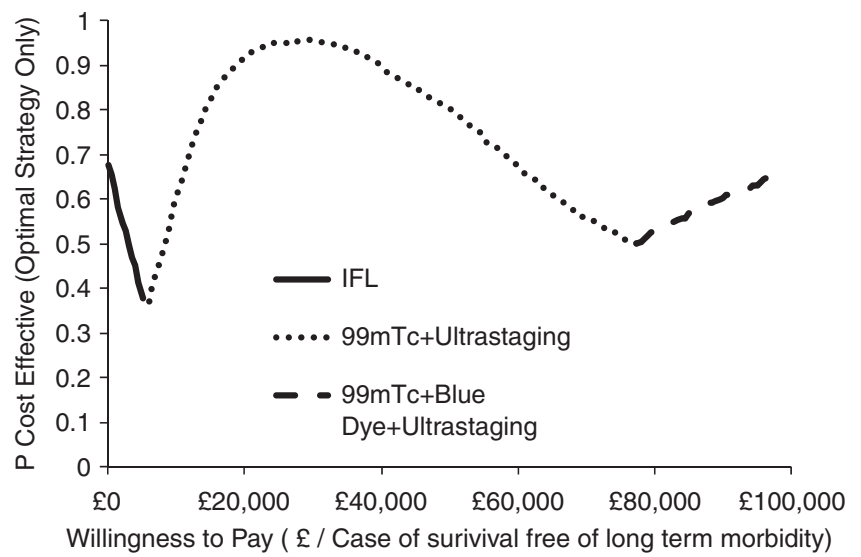

Figure A8: Cost-effectiveness acceptability frontier showing the results of the sensitivity analysis examining the optimal investigative strategy across a range of willingness to pay thresholds for the outcome of additional case of survival free of long-term morbidity

\section{One-way sensitivity analysis}

The results of the one-way sensitivity analysis are shown in the table below:

Table A4: Results of one-way sensitivity analysis

\begin{tabular}{|c|c|c|c|}
\hline Scenario & $\begin{array}{c}\text { ICER Overall survival at } 2 \\
\text { years }\end{array}$ & $\begin{array}{l}\text { ICER Survival free of morbidity } \\
\text { for } 2 \text { years }\end{array}$ & $\begin{array}{l}\text { ICER Survival free of long-term } \\
\text { morbidity for } 2 \text { years }\end{array}$ \\
\hline \multicolumn{4}{|l|}{ Baseline } \\
\hline $\begin{array}{l}\text { IFL } \\
\text { Blue dye + ultrastaging } \\
99 \mathrm{mTc}+\text { ultrastaging } \\
99 \mathrm{mTc}+\text { blue dye + ultrastaging }\end{array}$ & Dominates & $\begin{array}{l}£ 2400 \\
£ 4900 \\
£ 41200\end{array}$ & $\begin{array}{c}£ 3700 \\
£ 8900 \\
£ 74300\end{array}$ \\
\hline \multicolumn{4}{|l|}{ Age $=55$} \\
\hline $\begin{array}{l}\text { IFL } \\
\text { Blue dye + ultrastaging } \\
99 \mathrm{mTc}+\text { ultrastaging } \\
99 \mathrm{mTc}+\text { blue dye + ultrastaging }\end{array}$ & Dominates & $\begin{array}{l}£ 2300 \\
£ 4900 \\
£ 40900\end{array}$ & $\begin{array}{c}£ 3600 \\
£ 8800 \\
£ 73800\end{array}$ \\
\hline \multicolumn{4}{|l|}{ Age $=75$} \\
\hline $\begin{array}{l}\text { IFL } \\
\text { Blue dye + ultrastaging } \\
99 \mathrm{mTc}+\text { ultrastaging } \\
99 \mathrm{mTc}+\text { blue dye + ultrastaging }\end{array}$ & Dominates & $\begin{array}{l}£ 2400 \\
£ 5100 \\
£ 42600\end{array}$ & $\begin{array}{c}£ 4200 \\
£ 9000 \\
£ 76000\end{array}$ \\
\hline \multicolumn{4}{|c|}{ Increased mortality due to patient morbidity } \\
\hline $\begin{array}{l}\text { IFL } \\
\text { Blue dye }+ \text { ultrastaging } \\
99 \mathrm{mTc}+\text { ultrastaging } \\
99 \mathrm{mTc}+\text { blue dye }+ \text { ultrastaging }\end{array}$ & Dominates & $\begin{array}{l}£ 2300 \\
£ 4900 \\
£ 40700\end{array}$ & $\begin{array}{c}£ 3700 \\
£ 8700 \\
£ 72000\end{array}$ \\
\hline \multicolumn{4}{|c|}{ Cost of implementing $99 \mathrm{mTc}+$ blue dye together } \\
\hline \multicolumn{4}{|c|}{ Cost of $99 \mathrm{mTc}+$ blue dye $=$ cost $99 \mathrm{mTc}(£ 3836)$} \\
\hline $\begin{array}{l}\text { IFL } \\
\text { Blue dye }+ \text { ultrastaging } \\
99 \mathrm{mTc}+\text { blue dye }+ \text { ultrastaging }\end{array}$ & Dominates & $\begin{array}{l}£ 2400 \\
£ 4700\end{array}$ & $\begin{array}{l}£ 3700 \\
£ 8400\end{array}$ \\
\hline \multicolumn{4}{|c|}{ Cost of $99 \mathrm{mTc}+$ blue dye $=50 \%$ more than the cost of $99 \mathrm{mTc}(£ 5754)$} \\
\hline $\begin{array}{l}\text { IFL } \\
\text { Blue dye + ultrastaging } \\
99 \mathrm{mTc}+\text { ultrastaging } \\
99 \mathrm{mTc}+\text { blue dye + ultrastaging }\end{array}$ & Dominates & $\begin{aligned} £ 2400 \\
£ 4900 \\
£ 195700\end{aligned}$ & $\begin{array}{c}£ 3700 \\
£ 8900 \\
£ 352600\end{array}$ \\
\hline \multicolumn{4}{|c|}{ Groin recurrence rate following negative SLN biopsy result for metastasis $=2 / 31$} \\
\hline $\begin{array}{l}\text { IFL } \\
\text { Blue dye + ultrastaging } \\
99 \mathrm{mTc}+\text { ultrastaging } \\
99 \mathrm{mTc}+\text { blue dye + ultrastaging }\end{array}$ & Dominates & $\begin{array}{c}£ 2600 \\
£ 5200 \\
£ 42400\end{array}$ & $\begin{array}{c}£ 4300 \\
£ 9800 \\
£ 81300\end{array}$ \\
\hline
\end{tabular}




\begin{tabular}{|c|c|c|c|}
\hline \multicolumn{4}{|l|}{$=30 \%$} \\
\hline $\begin{array}{l}\text { IFL } \\
\text { Blue dye }+ \text { H\&E } \\
\text { Blue dye }+ \text { ultrastaging } \\
99 \mathrm{mTc}+\mathrm{H} \& \mathrm{E} \\
99 \mathrm{mTc}+\text { ultrastaging } \\
99 \mathrm{mTc}+\text { blue dye }+ \text { ultrastaging }\end{array}$ & Dominates & $\begin{array}{l}£ 4800 \\
\\
£ 7500 \\
£ 12000 \\
£ 54000\end{array}$ & $\begin{array}{l}£ 28400 \\
£ 41500 \\
£ 293400\end{array}$ \\
\hline \multicolumn{4}{|c|}{ Monitoring every 3 months for all pathways } \\
\hline $\begin{array}{l}\text { IFL } \\
\text { Blue dye }+ \text { ultrastaging } \\
99 \mathrm{mTc}+\text { ultrastaging } \\
99 \mathrm{mTc}+\text { blue dye }+ \text { ultrastaging }\end{array}$ & Dominates & $\begin{array}{c}£ 600 \\
£ 3500 \\
£ 39800\end{array}$ & $\begin{array}{c}£ 900 \\
£ 6300 \\
£ 71700\end{array}$ \\
\hline \multicolumn{4}{|c|}{ False positive result $=1.2 \%$ for all SLN biopsy pathways } \\
\hline $\begin{array}{l}\text { IFL } \\
\text { Blue dye }+ \text { ultrastaging } \\
99 \mathrm{mTc}+\text { ultrastaging } \\
99 \mathrm{mTc}+\text { blue dye }+ \text { ultrastaging }\end{array}$ & Dominates & $\begin{array}{c}£ 2400 \\
£ 5000 \\
£ 41700\end{array}$ & $\begin{array}{c}£ 3800 \\
£ 9000 \\
£ 75200\end{array}$ \\
\hline
\end{tabular}

Abbreviations: $\mathrm{H} \& \mathrm{E}=$ haematoxylin and eosin; ICER = incremental cost-effectiveness ratio; IFL=inguinofemoral lymphadenectomy; $S L N=$ sentinel lymph node. 